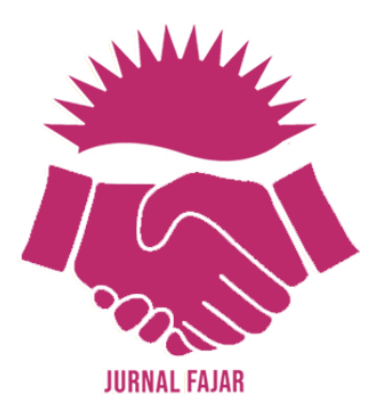

\title{
Pelatihan Menulis ARTIKel JURNal SECARA ONLINE BAGI MAHASISWA JURUSAN ILMU ALQURAN DAN TAFSIR IAIN TULUNGAGUNG*
}

\author{
$\mathcal{N}$ gainun $\mathcal{N a i m}$ \\ Institut Agama Islam Negeri Tulungagung \\ E-mail: naimmas22@gmail.com \\ $\underline{10.15408 / j f . v 20 i 2.20601}$
}

\begin{abstract}
:
Writing journal articles is one of the final assignments for students of the Department of Al-Qur'an and Tafsir (IAT), the Faculty of Ushuluddin, Adab, and Da'wah (FUAD) IAIN Tulungagung. Journal articles are clearly not as many as theses, however, it does not mean that when students choose journal articles for final assignments, they can do it easily and quickly. Many students actually experience difficulties so that the process of writing journal articles takes a long time. Based on its problems, this article is to provide solutions to the difficulties experienced by students. The activity was in the form of online training which was carried out for 3 meetings with a duration of 3 hours for each meeting. The implementation of activities via the Zoom application is due to the pandemic situation which makes face-to-face activities impossible. The method of implementing the activity is discussions, answers and questions, and the practice of writing journal articles. The results showed an increase in the knowledge and skills in writing journal articles. It is marked by the ability of students to write articles step by step in each meeting.
\end{abstract}

Keywords: Journal article, Writing skill, Mendeley, Training.

*Diterima 30 April 2020, Revisi 25 Mei 2020, Diterbitkan 30 Juni 2020.

Fajar: Media Komunikasi dan Informasi Pengabdian Kepada Masyarakat Vol 20 No 2 (2020) - 81 


\section{Abstrak:}

Menulis artikel jurnal menjadi salah satu pilihan tugas akhir bagi mahasiswa Jurusan Ilmu Al-Qur'an dan Tafsir (IAT) Fakultas Ushuluddin, Adab dan Dakwah (FUAD) IAIN Tulungagung. Dari sisi jumlah kata, artikel jurnal jelas tidak sebanyak skripsi. Namun, bukan berarti ketika mahasiswa memilih artikel jurnal untuk tugas akhir mereka bisa mengerjakan secara mudah dan cepat. Tidak sedikit di antara mahasiswa yang justru mengalami kesulitan sehingga proses pengerjaan artikel jurnal berlarut-larut dan memakan waktu yang panjang. Berdasarkan permasalahan tersebut maka tujuan pengabdian ini adalah memberikan solusi atas kesulitan yang dialami oleh mahasiswa. Kegiatan berupa pelatihan secara online yang dilaksanakan selama 3 kali pertemuan dengan durasi waktu tiap-tiap pertemuan 3 jam. Pelaksanaan kegiatan via aplikasi Zoom karena situasi pandemi yang tidak memungkinkan untuk mengadakan kegiatan tatap muka. Metode pelaksanaan kegiatan adalah ceramah, diskusi, tanya jawab, dan praktik penulisan artikel jurnal tahap demi tahap. Hasil pelatihan menunjukkan adanya peningkatan pengetahuan dan keterampilan mahasiswa peserta pelatihan dalam membuat artikel jurnal. Hal itu ditandai dengan kemampuan mahasiswa untuk menulis artikel tahap demi tahap dalam setiap pertemuan.

Kata Kunci: Artikel jurnal, Keterampilan menulis, Mendeley, Pelatihan. 


\section{Pendahuluan}

Ilmu pengetahuan telah mengalami perkembangan sangat dinamis dari waktu ke waktu. Perkembangannya semakin dinamis dalam beberapa tahun terakhir. Hadirnya ilmu pengetahuan berimplikasi pada terjadinya transformasi dalam kehidupan masyarakat.[1] Hal ini disebabkan karena masyarakat memanfaatkan produksi ilmu pengetahuan dan teknologi untuk kehidupannya. Media persebaran ilmu pengetahuan dan teknologi adalah lewat tulisan [2] yang dimuat di berbagai jurnal, buku, dan media lainnya. Tulisan, dengan demikian, memiliki peranan yang sangat penting dalam mendorong kemajuan masyarakat. Perspektif ini secara implisit menegaskan penting tradisi menulis bagi kemajuan masyarakat. Semakin banyak warga masyarakat yang memiliki keterampilan menulis maka akan berkorelasi positif pada tumbuhnya kemajuan.

Realitas masyarakat Indonesia masih belum menggembirakan dalam hal tradisi menulis. Rendahnya budaya tulis tidak hanya pada masyarakat umum melainkan juga pada mereka yang bergelut dengan dunia keilmuan. Padahal kalangan cendekiawan seharusnya menjadi role model dalam membangun tradisi menulis. Cendekiawan seharusnya memiliki komitmen kuat untuk membangun kultur ilmiah dan menulis [3]. Meskipun juga disadari bahwa menulis merupakan kegiatan yang tidak mudah. Banyak orang yang menganggap bahwa menulis merupakan kegiatan sederhana yang bisa dilakukan oleh siapa pun juga, termasuk mahasiswa. Namun anggapan ini tidak sepenuhnya benar. Menulis itu tidak sederhana karena berkaitan dengan aspek pengetahuan, sikap mental, dan juga keterampilan [4]. Aspek yang penting dalam menulis adalah penguasaan teori menulis dan praktik [5]. Teori memang penting tetapi tanpa pernah praktik tidak akan membuat seseorang bisa menulis. Praktik tanpa teori membuat hasilnya kurang sesuai dengan ketentuan. Perpaduan antara teori dengan praktik merupakan formula ideal yang memberikan kesempatan yang besar bagi dihasilkannya tulisan yang sesuai dengan harapan.

Jenis tulisan sangat beragam. Ada tulisan ilmiah, ada yang non-ilmiah. Secara sederhana tulisan ilmiah dibedakan menjadi beberapa jenis. Pertama, term paper atau disebut juga dengan short paper. Tulisan jenis ini biasanya disajikan di sebuah pertemuan ilmiah atau dimuat di jurnal ilmiah. Kedua, book report yaitu karya ilmiah yang dibuat dalam bentuk laporan yang bersifat rangkuman dari satu buku atau lebih dengan topik yang sama. Ketiga, book review, yaitu bentuk karya ilmiah yang menilai sebuah buku. Jenis ini biasanya dikenal juga sebagai resensi buku [6]. Keempat, kertas kerja yang menyajikan paparan berdasarkan data yang diolah dari hasil penelitian. Kelima, skripsi yaitu karya tulis jenjang strata satu yang ditulis berdasarkan penelitian di bawah pembimbing yang kompeten. Keenam, tesis, yaitu karya tulis jenjang strata dua yang ditulis berdasarkan penelitian di bawan pembimbing yang kompeten. Ketujuh, disertasi yaitu karya tulis jenjang strata tiga yang ditulis di bawah bimbingan promotor [7]. 
Artikel yang diterbutkan di jurnal ilmiah merupakan bentuk pertama atau term paper dalam tipologi ini. Artikel ilmiah memiliki manfaat yang sangat besar bagi kehidupan seorang dosen, bagi institusi, bagi masyarakat luas, dan bagi negara. Salah satu tolok ukur kemajuan sebuah bangsa adalah dari produktivitas masyarakatnya dalam menghasilkan karya tulis ilmiah. Karya tulis ilmiah bukan karya tulis yang dibuat asal-asalan melainkan melalui proses penelitian yang mengikuti standar ilmiah dan mematuhi terhadap etika keilmuan [8]. Ketaatan mengikuti prosedur menjadikan tulisan ilmiah memiliki validitas tinggi dan bisa dipertanggungjawabkan. Artikel jurnal memiliki karakter dan proses membuat yang khusus. Pengetahuan teoretis dan teknis tentang artikel jurnal sangat diperlukan agar proses pembuatannya bisa lancar. Keterbatasan pengetahuan dan minimnya latihan menulis berimplikasi pada terhambatnya proses menulis artikel [9].

Riset-riset terkait tema artikel jurnal sesungguhnya sudah cukup banyak dilakukan. Salah satu penelitian menelisik relasi yang cukup kuat antara penguasaan ragam bahasa Bahasa Indonesia standar dan keterampilan menulis artikel ilmiah di IKIP PGRI Pontianak [10], penguasaan tata Bahasa dan berpikir logis [11], penguasaan Mendeley dalam peningkatan kualitas artikel jurnal bagi dosen [12], dan perkembangan open acces jurnal ilmiah [13]. Ada juga riset yang dilakukan oleh Alfi Syahrini [14] yang fokusnya pada upaya optimalisasi budaya literasi di kalangan mahasiswa. Adapun pengabdian masyarakat terkait topik ini adalah pengabdian berupa pelatihan Turnitin dan Mendeley [15], pelatihan peningkatan kemampuan menulis bagi guru [16], [17], pendampingan penulisan artikel jurnal [18], dan pelatihan melalui web seminar [19].

Berbeda dengan penelitian dan pengabdian yang telah dilakukan sebelumnya, artikel ini membahas tentang pengabdian dengan fokus penulisan artikel jurnal. Pesertanya adalah mahasiswa Jurusan Ilmu Al-Qur'an dan Tafsir (IAT) IAN Tulungagung. Pelaksanaannya menggunakan Zoom karena situasi pandemi belum memungkinkan untuk melaksanakan pengabdian tatap muka. Mahasiswa Fakultas Ushuluddin, Adab, dan Dakwah (FUAD) IAIN Tulungagung, termasuk di dalamnya mahasiswa Jurusan Ilmu Al-Qur'an dan Hadis (IAT), bisa memilih artikel jurnal untuk menyelesaikan studinya. Secara sekilas artikel jurnal terlihat lebih ringan dibandingkan dengan skripsi. Jumlah halaman artikel jurnal tidak sebanyak halaman skripsi. Namun demikian dari sisi tata aturan, penulisan artikel jurnal bukan berarti lebih mudah. Berdasarkan wawancara dan diskusi dengan banyak mahasiswa, ternyata menulis artikel jurnal itu tidak semudah yang dibayangkan. Tidak sedikit mahasiswa yang akhirnya berhenti di tengah jalan karena gagal menyelesaikan penulisan artikel jurnal. Juga ada yang karena merasa tidak mampu menyelesaikan artikel jurnal akhirnya memilih skripsi. Padahal ia telah menghabiskan waktu berbulan-bulan untuk menulis artikel jurnal. 
Menulis bukan persoalan bakat, melainkan persoalan keterampilan [20]. Keterampilan tidak terbangun begitu saja. Dibutuhkan proses belajar dan terus belajar, praktik, dan kemudian menjadi sesuatu yang tidak perlu dipikiran pada saat melakukan. Keterampilan sesungguhnya merupakan perwujudan dari aktivitas demi aktivitas yang dilakukan secara berulang-ulang. Secara umum mahasiswa Jurusan Ilmu Al-Qur'an dan Tafsir (IAT) IAIN Tulungagung sesungguhnya sudah mendapatkan modal pengetahuan yang memadai tentang menulis dan hal-hal teknis yang terkait. Komposisi kurikulum yang disusun mempertimbangkan berbagai aspek secara baik [21]. Implementasi kurikulum dalam proses pembelajaran juga memberikan kesempatan kepada mahasiswa untuk mendapatkan pengetahuan dan keterampilan semaksimal mungkin.

Persoalannya, idealitas itu tidak selalu sejalan dengan realitas. Selalu ada jurang yang membuat antara apa yang diharapkan dengan praktik yang dilakukan. Justru di titik inilah diperlukan pemikiran, ide, dan gagasan yang kemudian ditindaklanjuti menjadi sebuah tindakan untuk menyelesaikan persoalan yang diidentifikasi. Salah satu persoalan yang kami identifikasi adalah menulis artikel jurnal. Kemampuan menulis artikel jurnal sesungguhnya berkaitan dengan keterampilan menulis itu sendiri. Artinya, jika seorang mahasiswa belum memiliki kebiasaan menulis maka saat ada kewajiban untuk membuat artikel jurnal tentu akan mengalami persoalan tersendiri. Sejauh ini belum ada matakuliah yang mendukung secara khusus pada terbangunnya keterampilan menulis artikel jurnal. Implikasinya ketika ada kewajiban membuat artikel jurnal sebagai ganti dari tugas akhir studi, banyak mahasiswa yang mengalami kebingungan. Kebingungan tersebut berkaitan dengan teori dan praktik menulis artikel di jurnal ilmiah. Realitas semacam ini tentu tidak bisa dibiarkan berlarut-larut. Harus dilakukan usaha-usaha kreatif yang bisa memberikan solusi. Usaha kreatif ini merupakan aktualisasi dari pembacaan terhadap realitas yang ada lalu dibangun berbagai kemungkinan untuk proses penyelesaiannya [22]. Pada titik inilah pengabdian masyarakat ini penting dilakukan sebagai ikhtiar untuk memberikan bekal pengetahuan dan modal untuk berlatih menulis artikel jurnal ilmiah. Lewat kegiatan ini diharapkan persoalan demi persoalan terurai atau paling tidak ada klarifikasi dan diskusi terkait persoalan artikel jurnal.

Pelatihan menulis artikel jurnal yang dilaksanakan secara online merupakan solusi atas persoalan yang ada. Lewat pelatihan ini mahasiswa diajak untuk berdiskusi, dibimbing, dan didampingi untuk praktik menulis tahap demi tahap. Proses pelatihan semacam ini memungkinkan bagi mahasiswa untuk memiliki pengetahuan tentang seluk-beluk artikel jurnal dan jurnal ilmiah. Aspek yang disampaikan bukan hanya teori tetapi juga praktik. Dengan demikian pelatihan ini memberikan solusi berupa pemecahan kesulitan mahasiswa IAT dalama membuat artikel jurnal ilmiah. 


\section{Metode}

Langkah pertama untuk pelaksanaan program adalah mendesain waktu pelaksanaan, metode pelaksanaan, dan hal-hal teknis lainnya. Hal ini penting dipertimbangkan karena perencanaan sebuah kegiatan secara baik akan menentukan keberhasilan pelaksanaan kegiatan. Perencanaan memungkinkan sebuah kegiatan dapat berjalan secara efektif dan efisien sesuai dengan tujuan yang telah disusun sebelumnya [23]. Pada tataran implementasi, kegiatan pengabdian ini diawali dengan membuat flyer pengumuman kegiatan. Flyer kemudian disebarkan kepada mahasiswa IAT Semester VII karena mereka sedang dalam proses menulis tugas akhir berupa artikel jurnal. Selain membuat flyer juga dibuat google drive untuk pendaftaran. Bagaimana pun juga peserta yang terdaftar harus jelas supaya bisa diperoleh gambaran tentang siapa saja yang ikut. Juga perlu dipikirkan untuk membangun komunikasi secara intensif dengan para peserta pelatihan di luar waktu pelaksanaan kegiatan. Komunikasi diperlukan agar bisa diperoleh gambaran tentang apa saja persoalan yang mereka hadapi. Juga tentang strategi yang mungkin untuk dilakukan dalam mengatasi persoalan yang tengah mereka hadapi dalam proses menulis artikel jurnal. Total peserta sebanyak 40 orang. Pelaksanaan kegiatan sebanyak 3 kali, yaitu pada Hari Minggu tanggal 29 Nopember 2020 mulai jam 7.30 sampai jam 10.00. Kegiatan kedua dilaksanakan pada 3 Desember, dan kegiatan ketiga dilaksanakan pada 10 Desember.

Metode kegiatan diawali dengan brainstorming terkait dengan persoalanpersoalan yang dihadapi oleh peserta. Waktu yang disediakan selama 30 menit. Dari brainstorming yang dilakukan diperoleh gambaran tentang persoalan apa saja yang dihadapi peserta terkait dengan pengetahuan dan proses pembuatan artikel jurnal. Hasil brainstorming kemudian dipetakan berdasarkan kategori yang disusun. Secara umum persoalan yang dihadapi oleh mahasiswa peserta pelatihan adalah terkait pengetahuan tentang artikel jurnal, proses kreatif penulisan, dan aspek teknis submit ke jurnal yang memakai sistem Open Journal System (OJS).

Pada tahapan selanjutnya penyampaian materi dengan mengacu kepada persoalan yang dihadapi oleh peserta. Paparan materi selama 1 jam. Tepat pukul 09.00 paparan selesai dan dilanjutkan tanya jawab selama 30 menit. Pada sesi terakhir peserta dipandu untuk membuat artikel tahap demi tahap. Demi memudahkan komunikasi dan konsultasi dibentuk WA grup. Pertemuan kedua dan ketiga diawali dengan paparan materi, Tanya jawab, koreksi atas tugas yang sudah selesai, dan dilanjutkan dengan praktik.

\section{Hasil dan Pembahasan}

Menulis artikel jurnal membutuhkan pengetahuan yang cukup tentang jurnal. Jurnal sekarang ini serba elektronik. Karena itu penguasaan terhadap 
aplikasi perangkat lunak penulisan menjadi kebutuhan mendasar. Selain itu juga penting menguasai teknik penulisan itu sendiri [24]. Persoalannya belum semua mahasiswa yang menjadi peserta kegiatan memahami secara baik terhadap hal ini. Padahal idealnya studi itu diikuti dengan pembangunan tradisi literasi. Membaca dan menulis menjadi aktivitas sehari-hari mahasiswa. Sepanjang proses studi mahasiswa dibiasakan dengan aktivitas menulis, baik ilmiah maupun ilmiah popular [25]. Implikasinya, mahasiswa akan terbiasa dalam menghasilkan karya tulis, termasuk menghasilkan artikel jurnal.

Pada sesi pelaksanaan kegiatan pertemuan pertama dibahas tentang selukbeluk jurnal ilmiah elektronik. Jurnal ilmiah di Indonesia, berdasarkan Peraturan Kepala LIPI Nomor 3 Tahun 2014 dan Dirjen Dikti No. 1 Tahun 2014 tentang akreditasi terbitan berkala ilmiah, harus berbentuk elektronik untuk memenuhi akreditasi. Implikasi dari kebijakan ini, jurnal ilmiah yang awalnya berbentuk cetak harus bertransformasi menjadi elektronik dengan memakai Open Journal Systems (OJS) [26]. Jurnal cetak tetap bisa terbit namun sistem elektronik harus juga dikelola secara baik. Data di https://sinta.ristekbrin.go.id/journals menyebutkan bahwa sekarang ini ada 5148 jurnal yang telah terakreditasi. Pada paparan ini disampaikan kepada para peserta tentang level akreditasi, cara mencari jurnal, dan hal-hal teknis lainnya.

Setelah disampaikan materi tentang jurnal elektronik disampaikan materi tentang penulisan artikel jurnal. Aspek yang pertama disampaikan adalah mencari jurnal yang sesuai dengan minat. Peserta diajak masuk ke laman https://sinta.ristekbrin.go.id// lalu mencari menu sources dan klik journals. Sesuai dengan bidang ilmu peserta maka diajarkan untuk mencari jurnal yang sesuai dengan bidang ilmu dengan mengetik kata kunci di Advance Search. Ketika diketik kata "Al-Qur'an" muncul dua jurnal, yaitu Jurnal Suhuf (S2) dan Jurnal Mumtaz (S5). Ketika diketik kata "Tafsir" muncul delapan jurnal. Pilihan lainnya adalah mengetik kata "Islam" dan ditemukan sebanyak 352 jurnal. Beberapa kata lain bisa dicari dengan tujuan menemukan jurnal yang sesuai dengan minat masing-masing peserta. Setelah menemukan jurnal yang masuk prioritas maka jurnal tersebut dikunjungi, dibaca author guidelines-nya dan dicermati template-nya. Aspek ini penting dilakukan karena sebuah artikel yang dikirim ke jurnal pertama-tama harus sesuai dengan template yang sudah ditentukan. Template merupakan format baku penulisan di sebuah jurnal yang harus diikuti oleh orang yang akan mengirimkan artikel [27].

Setelah mengetahui template jurnal maka peserta diajak untuk mencermati author guide line. Pada bagian ini pembaca bisa membaca apa saja hal-hal teknis yang harus dipenuhi dalam penulisan artikel. Misanya sebuah jurnal mensyaratkan jumlah kata sebanyak 2500-3000. Ada juga jurnal yang mensyaratkan jumlah kata sebanyak 10.000. Jika jumlah kata tidak memenuhi ketentuan maka besar kemungkinan artikel akan ditolak. Begitu juga dengan hal- 
hal lainnya seperti sistem penulisan sumber rujukan.

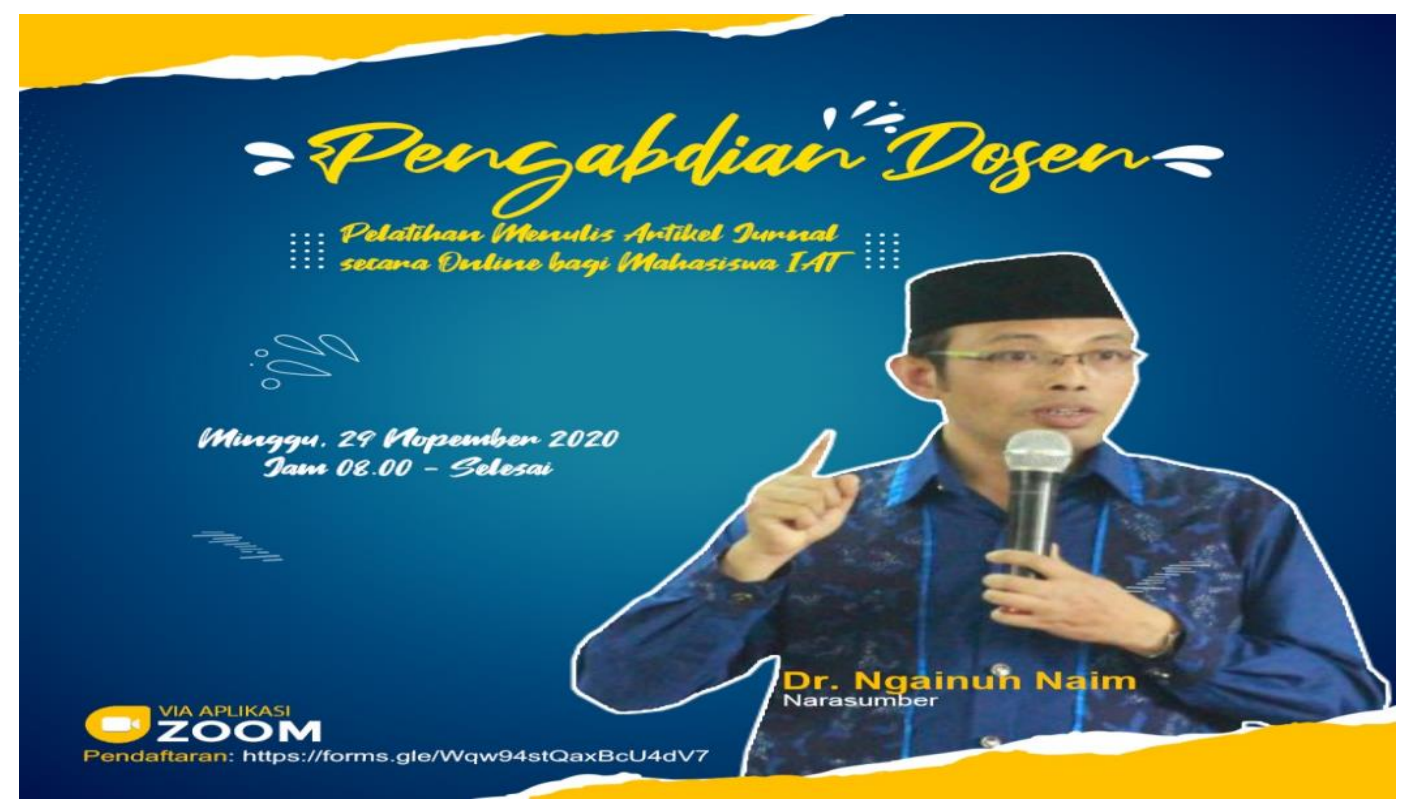

Pada tahap selanjutnya dijelaskan tentang struktur artikel jurnal. Pertamatama adalah judul. Judul yang baik itu ringkas, tidak terlalu panjang, padat, dan to the point. Setelah itu nama penulis, institusi afiliasi, dan email. Nama ditulis tanpa gelar. Bagian selanjutnya adalah abstrak. Jumlah kata abstrak artikel jurnal biasanya antara 200-250 kata yang memuat latar belakang, tujuan, metode, kesimpulan. Penyusunannya harus dibuat sebaik mungkin karena abstrak merupakan saripati artikel jurnal. Pembaca umumnya akan tertarik membaca isi artikel jika abstraknya menarik. Di bawah abstrak adalah kata kunci yang jumlahnya biasanya lima, mewakili isi jurnal, dan ditulis urut sesuai abjad.

Setelah penjelasan selesai dilanjutkan dengan tanya jawab. Cukup banyak pertanyaan dari peserta, namun karena waktu yang terbatas maka pertanyaan dibatasi untuk lima orang. Setelah menjawab pertanyaan peserta kemudian diajak untuk praktik membuat judul artikel dan membuat abstrak. Praktik ini sangat penting karena menulis itu bukan sekadar teori tetapi harus juga praktik. Tidak sedikit orang yang aktif dalam seminar, pelatihan, dan workshop tetapi tetap mengalami kesulitan menulis karena tidak pernah praktik menulis [7]. Oleh karena itu jika ingin berhasil dalam menulis ilmiah maka harus praktik menulis sesering mungkin. Segala hambatan harus disingkirkan. Bentuk-bentuk hambatan yang seringkali dihadapi dalam menulis adalah tidak memiliki gairah menulis, memiliki semangat tetapi selalu ada alasan untuk tidak menulis, takut salah, merasa tulisannya tidak bermutu, dan berbagai hambatan lainnya [28].

Pertemuan kedua dilaksanakan pada Hari Minggu tanggal 3 Desember 2020. Acara dimulai jam 07.30 dengan melakukan evaluasi atas tugas yang 
diberikan pada pertemuan pertama. Setelah evaluasi selama satu jam kemudian dilanjutkan dengan penjelasan tentang pendahuluan. Pendahuluan pada dasarnya menjelaskan tentang empat hal. pertama, menjelaskan tentang fenomena atau isu apa yang diangkat ditinjau dari sisi signifikansinya. Sebaiknya didukung dengan data-data yang memadai. Kedua, menjelaskan data-data singkat tentang apa yang sudah ditulis orang terkait fenomena yang ditulis dan kekurangannya di mana. Ketiga, menjelaskan tentang bagaimana artikel yang akan ditulis merespon terhadap kekurangan yang ada dan menawarkan hal apa. Dan keempat, menjelaskan tentang tujuan dari artikel ditulis.

Bagian berikutnya adalah review literature. Bagian ini menjelaskan tentang bagaimana review literature dibuat. Sebagai sebuah keterampilan, review literature harus sering dilatih proses penulisannya. Ia tidak bisa dikuasai begitu saja tanpa pernah berlatih. Ditinjau dari sisi pengertian, review literature adalah metode yang sistematis, eksplisit, dan reprodusibel dalam melakukan indetifikasi, evaluasi, dan sintesis terhadap karya-karya hasil penelitian dan hasil pemikiran yang dihasilkan oleh para peneliti. Tujuan dari review literature adalah untuk melakukan analisis dan sintesis terhadap pengetahuan yang sudah terkait dengan topik yang sedang diteliti. Lewat review literature inilah bisa ditemukan ruang kosong atau novelty dari artikel yang sedang ditulis [29]. Dalam penjelasan tentang review literature banyak dipaparkan contoh-contoh dari artikel jurnal. Contoh demi contoh yang dipaparkan diharapkan lebih memudahkan peserta untuk memahami dan berikutnya juga menyusun review literature.

Bagian selanjutnya adalah penjelasan tentang metode penelitian. Artikel jurnal merupakan artikel hasil penelitian. Metode penelitian menjelaskan tentang apa, mengapa, dan bagaimana penelitian dilakukan. Metode sebaiknya dijelaskan secara ringkas, padat, dan memberikan informasi yang memadai tentang bagaimana penelitian dilakukan. Bagi mahasiswa IAT, metode penelitiannya bisa studi literatur [30], bisa juga lapangan [31]. Peserta pelatihan semua sudah mendapatkan matakuliah metode penelitian. Namun demikian mereka belum memiliki pengalaman yang matang saat mengimplementasikan metode penelitian dalam penulisan artikel jurnal. Penjelasan dalam kegiatan ini diharapkan bisa memberikan pengetahuan dan juga praktik menulis metode penelitian.

Kegiatan pertemuan kedua diakhiri dengan diskusi. Berbagai pertanyaan muncul dari para peserta. Setelah selesai agenda berikutnya adalah penugasan untuk menyusun latar belakang dan metode penelitian. Penugasan diharapkan sudah selesai sebelum pertemuan ketiga pada tanggal 10 Desember. Komunikasi terkait tugas dilaksanakan melalui grup WA.

Bagian akhir pertemuan kedua adalah penjelasan tentang Mendeley. Penguasaan Mendeley sangat penting dalam penulisan artikel jurnal. model penulisan rujukan secara manual sudah tidak sesuai dengan perkembangan zaman. Jurnal ilmiah semuanya mensyaratkan penulisan referensi dengan 
menggunakan aplikasi seperti Mendeley. Hal ini sesungguhnya memudahkan para penulis dalam mengelola sitasi dan penulisan daftar pustaka [32]. Peserta pelatihan sebagian besar belum mengetahui tentang Mendeley. Padahal jika mau berlatih, tidak perlu waktu yang lama untuk menguasai. Kegiatan pelatihan ini memberikan kesempatan kepada peserta untuk bisa menguasai Mendeley secara baik.

Pertemuan ketiga dilaksanakan pada hari Minggu tanggal 10 Desember. Pada pertemuan ini ternyata belum semua peserta bisa menyelesaikan tugas yang diberikan. Berdasarkan hasil diskusi di awal pertemuan diperoleh informasi bahwa ternyata sebagian peserta masih mengalami kesulitan saat harus menuangkan tulisan di bagian pendahuluan, review literature dan metode. Kondisi sesungguhnya wajar dan dialami oleh siapa pun yang menulis artikel jurnal. Persoalan utamanya pada latihan. Bagi yang belum terlatih menulis, menuangkan gagasan itu bukan persoalan mudah. Justru pada kondisi semacam inilah pelatihan ini penting dilaksanakan. Diskusi, bimbingan, dan koreksiwalaupun dilaksanakan secara daring-diharapkan bisa mengurai sarang kesulitan yang dihadapi oleh peserta pelatihan. Pada pertemuan ketiga dibahas tentang hasil dan diskusi. Hasil ditulis dengan mengacu kepada rumusan masalah yang telah disusun sebelumnya. Data-data yang telah diolah disajikan secara detail sebagaimana rumusan masalah. Setelah selesai penjelasan kemudian didiskusikan tindak lanjut pelatihan, yaitu menyelesaikan artikel jurnal. Proses komunikasi dilakukan melalui grup WA.

\section{Kesimpulan}

Setelah melakukan kegiatan pengabdian berupa pelatihan penulisan artikel jurnal secara online maka kesimpulan yang bisa disampaikan adalah banyak sekali manfaat yang diperoleh oleh peserta. Pelatihan yang dilaksanakan selama tiga kali pertemuan memberikan kontribusi yang nyata bagi peserta dalam proses peningkatan pengetahuan dan keterampilan hal menulis artikel jurnal. Keterampilan menulis artikel jurnal bukan hanya bermanfaat bagi mahasiswa dalam menyusun artikel jurnal sebagai tugas akhir dalam menyelesaikan studi, melainkan juga berkontribusi dalam membangun kultur akademik di IAIN Tulungagung. Semakin banyak mahasiswa yang mampu menyelesaikan tulisannya dan kemudian dimuat di jurnal ilmiah akan berimplikasi secara nyata pada institusi. Namun, demikian juga disadari bahwa kemampuan menulis artikel jurnal itu tidak bisa terbangun secara instan. Dibutuhkan proses yang panjang dan berkelanjutan. Tiga kali pertemuan sesungguhnya belum bisa memberikan bekal secara tuntas kepada peserta. Meskipun demikian pelatihan ini penting artinya seagai ikhtiar memberikan kontribusi akademik bagi terbangunnya kultur menulis artikel jurnal ilmiah. 


\section{Referensi}

[1] S. Habibah, "Implikasi Filsafat Ilmu Terhadap PerkembanganIlmu Pengetahuan dan Teknologi. DAR EL-ILMI," Jurnal Studi Keagamaan, Pendidikan Dan Humaniora, 2017.

[2] M. Maftukhin, "ILMUWAN, ETIKA DAN STRATEGI PENGEMBANGAN ILMU PENGETAHUAN DI INDONESIA," Epistemé: Jurnal Pengembangan Ilmu Keislaman, 2015, doi: 10.21274/epis.2015.10.1.199-226.

[3] A. R. Damayantie, "Literasi Dari Era Ke Era," Sasindo: Jurnal Pendidikan Bahasa dan Sastra Indonesia, 2015.

[4] N. Nair, Subadrah \& Muniandy, "Peningkatan Kemahiran Menulis Melalui Kaedah STAD Pengenalan Kemahiran Menulis Pendekatan Koperatif," Pendidikan Bahasa, 2005.

[5] M. Yunus, "Hakikat Menulis," Modul 1, 2014.

[6] N. Naim, Proses Kreatif Penulisan Akademik, 5 ed. Tulungagung: Akademia Pustaka, 2019.

[7] S. \& A. Jihad, Cara Cepat Belajar Menulis Karya Ilmiah, 1 ed. Yogyakarta: Multi Pressindo, 2014.

[8] Mahyuddin K. M. Nasution, "Karya Ilmiah,” Medan, 2017.

[9] F. Hanum, "Strategi Penulisan Karya Ilmiah," Strategi Penulisan Karya Ilmiah, 2009.

[10] dan Muhammad Lahir, "Hubungan Penguasaan Ragam Bahasa Indonesia Standar Dengan Keterampilan Menulis Artikel Ilmiah," Jurnal Pendidikan Bahasa, 2018.

[11]Y. Agustin, "Penguasaan Tata Bahasa Dan Berpikir Logik Serta Kemampuan Menulis Artikel Ilmiah," Jurnal Ilmiah Kependidikan, 2015.

[12]C. Rahmawati, M. Meliyana, Y. Yuliana, dan H. Zain, "Pelatihan Software Mendeley Dalam Peningkatan Kualitas Artikel Ilmiah Bagi Dosen," JURNAL PENGABDIAN KEPADA MASYARAKAT, 2018, doi: 10.30999/jpkm.v8i1.200.

[13]Lukman, E. Marlina, Keumalasari. Ratih, A. H. A. M. Siagian, dan R. Slamet, "Perkembangan Open Access Jurnal Ilmiah Indonesia," Prosiding Konferensi Perpustakaan Digital Indonesia (KPDI) ke-5, 2012.

[14]A. Syahriyani, “Optimalisasi budaya literasi di kalangan mahasiswa: upaya meretas komunikasi global," Jurnal UI Untuk Bangsa Seri Sosial dan Humaniora., 2010.

[15]D. Hartanto, W. D. P. Rengga, Z. A. S. Bahlawan, I. N. Pradnya, W. Sammadikun, dan A. Sutrisno, "PELATIHAN APLIKASI TURNITIN DAN MENDELEY SOFTWARE BAGI MAHASISWA UNNES DALAM RANGKA PENINGKAATAN KOMPETENSI," AMALIAH: JURNAL PENGABDIAN KEPADA MASYARAKAT, 2019, doi: 10.32696/ajpkm.v3i1.239. 
[16]“PENINGKATAN KEMAMPUAN MENULIS ARTIKEL ILMIAH SAINS GURU SEKOLAH DASAR MELALUI KEGIATAN PENGABDIAN MASYARAKAT," Jurnal Abdimas, 2013.

[17]K. S. Arta, "PELATIHAN PENULISAN ARTIKEL UNTUK PUBLIKASI DI JURNAL ILMIAH UNTUK MENINGKATKAN PROFESIONALISME BAGI GURU-GURU DI KECAMATAN KUBUTAMBAHAN KABUPATEN BULELENG," Acarya Pustaka, 2019, doi: 10.23887/ap.v5i2.17412.

[18]I. Gunawan, T. Triwiyanto, dan D. E. Kusumaningrum, "Pendampingan Penulisan Artikel Ilmiah bagi Para Guru Sekolah Menengah Pertama," Abdimas Pedagogi: Jurnal Ilmiah Pengabdian kepada Masyarakat, 2018.

[19]A. Firmansyah, A. Arham, dan R. A. Qadri, "PELATIHAN MELALUI WEB SEMINAR TERKAIT PENULISAN ARTIKEL BERBASIS BIBLIOGRAPHICAL RESEARCH METHOD DALAM BIDANG AKUNTANSI UNTUK PUBLIKASI PADA JURNAL INTERNASIONAL BEREPUTASI," INTEGRITAS: Jurnal Pengabdian, 2020, doi: 10.36841/integritas.v4i1.564.

[20]G. Galli, "How to Write a Successful Science Thesis," Macromolecular Chemistry and Physics, 2006, doi: 10.1002/macp.200600524.

[21]N. Huda, "MANAJEMEN PENGEMBANGAN KURIKULUM," AL-TANZIM: JURNAL MANAJEMEN PENDIDIKAN ISLAM, 2017, doi: 10.33650/altanzim.v1i2.113.

[22]R. Ismayani, "Kreativitas Dalam Pembelajaran Literasi Teks Sastra," Jurnal Ilmiah Program Studi Pendidikan Bahasa dan Sastra Indonesia, 2013.

[23]F. Maujud, "Implementasi Fungsi-Fungsi Manajemen dalam Lembaga Pendidikan Islam (Studi Kasus Pengelolaan Madrasah Ibtidaiyah Islahul Muta'allim Pagutan)," JURNAL PENELITIAN KEISLAMAN, 2018, doi: 10.20414/jpk.v14i1.490.

[24]W. Darmalaksana, "Panduan publikasi ilmiah: Perangkat aplikasi, standar penulisan dan etika kepengarangan," Jurnal Riset dan Inovasi, 2017.

[25]K. A. Jasmi, "Mahasiswa dan Penulisan Kerta Kerja Akademik," dalam Mahasiswa dan Kehidupan dari Perspektif Islam, 2015.

[26]Y. Y. Prasetyawan, "Perkembangan Open Access dan Kontribusinya bagi Komunikasi Ilmiah di Indonesia," Anuva, 2017, doi: 10.14710/anuva.1.2.93-100.

[27]W. Darmalaksana, "Paper Template Design Thinking Methods for Learning Hadith," Pusat Studi Data Ushuluddin UIN Sunan Gunung Djati Bandung, 2019.

[28]J. P. Sitorus, "LITERASI DIGITAL: KONTRIBUSI DAN TANTANGAN DALAM KETERAMPILAN MENULIS," ALFABETA: Jurnal Bahasa, Sastra, dan Pembelajarannya, 2019, doi: 10.33503/alfabeta.v2i2.612.

[29]T. Rahayu, S. Syafril, I. S. Wekke, dan R. Erlinda, "Teknik Menulis Review Literatur Dalam Sebuah Artikel Ilmiah Titik," Metrologia, 2015.

[30]Melfianora, "Penulisan Karya Tulis Ilmiah dengan Studi Literatur," Open Science Framework, 2019. 
[31]H. S. Ahimsa-Putra, “THE LIVING AL-QUR'AN: BEBERAPA PERSPEKTIF ANTROPOLOGI," Walisongo: Jurnal Penelitian Sosial Keagamaan, 2012, doi: 10.21580/ws.20.1.198.

[32]E. Kusmayadi, "Pemanfaatan Aplikasi Mendeley untuk Mengelola Artikel Jurnal Online," Pelatihan Pemanfaatan Aplikasi Mendeley di Perpustakaan Univeritas Al'Azhar, Desember 2013., 2013. 
94 - Ngainun Naim 